\title{
THE Study ON THE FunCtionalization Role of STUdent Parents in EDUCATION ACTIVITIES
}

\author{
Aloysius Mering \\ Universitas Tanjungpura, Pontianak, Indonesia \\ E-mail:mering7157@yahoo.co.id
}

\begin{abstract}
This study aims to examine and describe the school's efforts to function the role of students parents in the education process at school. Descriptive research methods are used to achieve the research objectives. The study sample was parents and teachers who were purposively determined on the basis of considering the status of school accreditation. The schools selected as samples were Santun Untan Senior High School (accredited B) and Gembala Baik Senior High School (accreditation A). The research data was collected by interview instruments, questionnaires, and documentation. Data analysis was carried out by descriptive statistical studies to describe the optimal functioning of parents by schools. From the research data obtained the fact that the perceptions of parents of students and teachers in Santun Untan Senior High School and Gembala Baik Senior High School toward the relationship between parents and teachers are "good." In playing the functions of parents in school, both parents and teachers state "no difficulties." Aspects that are considered "important" to "very important" in fostering parent and teacher relationships include not giving up children's affairs to schools, assuming parents as school partners, parents controlling children's education, parents always following the development of the school, and care about children's education. With this perception, it is possible to "ideal conditions" in building optimal cooperation in student education in the two sample schools.
\end{abstract}

Keywords: Functionalization; Parents Role; Education Activities

\section{INTRODUCTION}

Student education services in schools demand optimal cooperation from parents and schools. Arief Rachman (Komarudin, 2015: 183) that;

"Students will develop well if parents can understand the school where their children learn and the school can appreciate the views and contributions of parents. Both parties can complement, complement, remind and perfect so that students get optimal service".

Arief Rachman mentioned the requirements for the development of children in schools, namely reciprocal contributions from schools and parents. These reciprocal contributions will complement each other's roles. Meanwhile, according to LJ (Friday, April 13, 2018) "the relationship between parents and schools represented by the School Committee is generally done to solve students' problems, if students get a warning letter (SP), initial introduction to the school year or just to receive reports student education." According to him, "School Committees or parents are not at all involved in planning school activities".
Understanding the role also means understanding student behavior and its relation to the behavior of parents or teachers. Daniel Goleman (language transfer, Hermaya, 1999: 269) explains that child behavior is a picture of parental treatment of children. Quoting the findings of the University of Washington Team, Daniel Goleman explained that emotionally skilled parents have children whose relationships are better. Another advantage he explained was that these children were more popular and preferred by their peers and by their teachers, including in cognitive matters. Daniel Goleman concludes that the benefits for children whose parents are emotionally skilled are a series of amazing benefits, which cover the entire spectrum of emotional intelligence, even more. So, such information needs to be conveyed by the teacher to parents. Information about educational behavior in the family and its consequences for the school or vice versa is exchanged honestly by both parties.

There should be a parallel line between parents and teachers in the process of children's education. In the sense of space, education is not only a monopoly in the classroom learning process, but also in the playground and at home. Therefore, so that children are not confused, there should be 
no differences between the three spaces. Parallel lines between parents and teachers in children's education are carried out through good cooperation designs.

The difficulty of cooperation between parents and teachers according to Zamroni (2003: 36) is an educational orientation that tends to treat students as objects or clients, while teachers as the highest scientific and indoctrinator authority, subject-oriented, and centralized management. Zamroni said that the practice of education isolates itself from real life outside of school, the teacher is fixated on narrow thinking, less precise and less sensitive in anticipating the problems faced by the world of education. This situation is most prominent as a cause of the gap between schools and parents.

In general, there has not been an even effort made by schools to involve parental participation in education. According to Zamroni (2003: 43), the participation of parents and society in school life is the main capital in the education process. School and parent cooperation also included involving school principals and administrative staff.

The quality of the school relationship (teacher) with parents is described by Arief Rachman (Ukim Komarudin, 2015: 183) as a relationship that fills, complements, reminds, and perfects so that students get optimal service ". The quality of the relationship will be explored further in this study. In detail, the problems that will be examined include, how (1) the school's perceptions of the relationship with parents of students, (2) parents' perceptions of relations with schools, (3) school efforts involving parents in school education, (4) the quality of school (teacher) relations with parents in the education process, and (5) what difficulties schools face in involving parents in school education.

The terms that need to be explained in this study are:

1. Functionalizing the role of parents of students

Functionalization in this study means making a role or functioning or a thing to make a function (KBI Third, 2002: 323) parents of students in the process of education of students at school. Specifically the functioning of the School Committee (POMG or BP3) as the parents' representative in the school. The criteria for parents "functioned" by the school is the optimal or important role of parents in school activities. The category is "very optimal (very important)", "optimal (important)", "quite optimal (important enough)", "less optimal (less important)", and "not optimal (not important)". A closed questionnaire was used and interviews with parents, students, teachers, and principals to get data about the functionalization of the parent's role.

2. Educational Activities

Educational activities in this study are all activities carried out by the school in the context of the learning process. These activities include curricular activities, cocurricular and extra-curricular activities. The stages of parental involvement are at the stage of planning, implementing, and evaluating activities. To obtain data on parental involvement through documentation studies, interviews, and questionnaires.
3. School perceptions and parents of students

Perception in this research is parents or school responses (teachers) about the functionalization of their respective roles in the education process. This perception was assessed by the categories "very positive," "positive," "quite positive," "less positive," and "very positive." The questionnaires and perceptual scales are used to obtain data on perceptions of parents and teachers (schools).

4. Quality of relationships (parents and school / teacher) Quality refers to the level of badness (level) of the relationship between the school and parents of students. The size of the bad is assessed the intensity of parents' involvement by the school and in what ways they are involved. The involvement is categorized as "very good", "good", "good enough", "not good", and "not very good". Data on the quality of the relationship between school and parents of students are obtained by questionnaire and scale of scores.

\section{Methodology}

Descriptive research methods are used to achieve the research objectives. The research sample was parents and teachers from Senior High Schools who were purposively determined on the basis of considering the status of school accreditation. The schools selected as samples were Santun Untan Senior High School in Pontianak (accredited B) and Gembala Baik Senior High School in Pontianak (accreditation A). The research data was collected by interview instruments, questionnaires, and documentation. Data analysis was carried out by descriptive statistical studies to describe the optimal functioning of parents by schools.

\section{RESULTS AND DISCUSSION}

\section{A. Results}

Overall, "Functionalization of the Role of Parents in Santun Untan Senior High Schools and Gembala Baik Senior High School" according to parents' assessment is "good" and the score is 69. This assessment is the same as the teacher's assessment, which is "good." When looking at the assessment aspects, the best score (very good) is in the statement that "there is no difficulty in the relationship between the school (teacher) and the parents of the students. The lowest rating is on "teacher perceptions of parents," namely "good" with the lowest score of 63 .

1. Findings at Santun Untan Senior High School

In choosing schools, the lowest consideration according to the teacher is that "the family has gone to school there" (score 40 or less important). But according to parents the reason "the family had gone to school there" was declared "very important" (score 89). Very important reasons for parents to choose a school are (1) complete facilities, (2) results of school graduates, (3) relationships with good schools, (4) guaranteed child moral education, (5) student achievement, (6) views the community towards schools, (7) good school and parent cooperation, (8) schools do not 
bother parents, (9) there is a sense of security in school children in the school. Other aspects that are considered "important enough" are (1) school activities, discipline, teacher attention, (2) distance from school to home, and (3) good experience with school in the past. This assessment is different from the teacher appraisal. According to the teacher, all aspects are "important" (grades 61-80). Only aspects (1) of school-home distance, (2) schools do not bother parents and (3) past experience with schools that are considered "quite important." For acceptance of new students, consideration of parents in choosing a school "very important" to be used as a benchmark.

Relating to "parental involvement in the education process in schools," data from parents and teachers show aspects that "often" involve parents in terms of (1) cultivation of character, and (2) choosing schools. According to parents, the aspects that need to involve parents are (1) Giving time to accompany the child to study, (2) accompanying the child to learn, (3) giving attention and affection in learning, (4) instilling character, (5) school selection, (6) providing additional lessons, (7) reminding schools in choosing and carrying out activities. According to the teacher, in addition to planting the character and selection of schools, the role of parents who "often" need to be involved are (1) selection of majors, (2) support for children participating in extra-curricular activities, (3) meeting school invitations, (4) fulfillment of school needs, and (5) support for school activities.

The quality of parent relationships with schools (teachers) is stated to be "very important" in terms of (1) helping children develop creativity related to subjects and interests, (2) aligning attitudes towards children, and (3) discussing child problems. Other aspects are considered "quite important." For teachers, aspects that are considered "very important" are (1) motivation for children, (2) supervision of children's activities, (3) reminding children's habits in learning, and (4) aligning attitudes toward children.

All aspects related to "are there difficulties with school, parents answer" no difficulties ", especially in terms of (1) meeting homeroom teacher, (2) meeting teacher, (3) giving advice, (4) working together, (5) discuss the interests of children, and (6) know the score of children, except to meet the principal "quite easily". The same assessment was stated by the teacher who stated that "there is no difficulty in all aspects, except meeting the principal," quite easy."

2. Findings at Gembala Baik Senior High School

Aspects that are considered "important to very important" in the relationship of parents and teachers are (1) do not consider parent education to be low, (2) do not consider parents do not understand school affairs, (3) provide assistance to schools, (4) matters relating to children, (5) not giving up children's affairs to schools, (6) assuming parents as school partners, (7) not demanding over school, (8) helping as needed, (9) controlling children's education strictly , (10) do not bother the school, (11) follow the development of the school, (12) feel the child is safe at school, and (13 cares about children's education. This assessment is almost the same as the teacher's assessment, i.e., all aspects are considered "important" to "very important "in the functioning of parents in children's education in school.

In terms of choosing a school, the aspects that are considered "very important" are (1) complete facilities, (2) graduate results, (3) school activities, discipline, and teacher attention, (4) school-family relationships, (5) education child health is guaranteed, (6) student achievement, (7) college absorptive capacity for graduates, (8) community views on school, (9) cooperation with schools, and (10) there is a sense of security if the school is there. Only four aspects, namely (1) families have gone to school there, (2) distance from school to home, (3) school does not bother parents, and (4) good experience in the past with schools that are "not made an important reason" in choose school. The parent's assessment is the same as the teacher's assessment.

Regarding the involvement of parents in education in Gembala Baik Senior High School, parents think that the "very important" aspects are (1) cultivating character, (2) creating an atmosphere of learning, (3) choosing schools, (4) supporting children to follow extra-curricular, (5) fulfilling school invitation, (6) fulfilling children's school needs, and (7) giving support to school activities. According to the teacher, "very important" aspects are (1) cultivation of character, (2) fulfillment of children's needs, and (3) provide support for school activities. Other aspects, such as (1) giving time to accompany learning, (2) accompanying children to learn, (3) giving input requested or not, (4) holding formal discussions/not being seen as "important enough." According to the teacher, other aspects were only declared "quite important".

The quality of parent relationships with teachers (schools) in Gembala Baik Senior High School is reflected in aspects (1) motivating children, (2) supervising children's activities, (3) improving good habits in children, (4) explaining children's attitudes, and (5) Helping children develop their creativity is a "frequent" aspect of concern in school collaboration with parents. Only aspects (1) establish relationships and (2) discuss child problems "sometimes" just pay attention. This assessment by the teacher, most of which are stated "often" is also considered. Two aspects of concern according to the teacher are (1) improving children's habits in learning and (2) helping children in developing creativity.

In Gembala Baik Senior High School, parents rate "very easy" or "no difficulty" to meet with the principal, homeroom teacher, give advice, work together, discuss children's interests, and know the score of the child. The same score is given by the teacher, except to work together and discuss the interests of the child given an "easy" score.

\section{B. Discussion}

In general, in the two respondent schools (teachers and parents) studied stated: "there is no difficulty in the relationship between the school (teacher) and parents of students". 
1. School perceptions about relationships with parents

Positive or negative perceptions depend on how one perceives the object of perception. This perception is influenced by a number of factors. As explained by Anita E. Woolfolk, Lorraine McCune-Nicolich (Educational Psychology for Teachers, 1984: 197) "many factors influence perception, including expectations, beliefs, and general saver principles for organizing information from the senses." So, the expectations and beliefs of the school towards parents greatly determine the quality and form of parental involvement in the education process at school.

From the research data, it was obtained the fact that in senior high school parents Santun towards the relationship between parents and teachers (school) was "good," while the teacher's perception was also "good." At Gembala Baik Senior High School Both teachers and parents view aspects that are considered "important" to "very important" in the relationship of parents and teachers is not to consider parental education as low, do not consider parents do not understand school affairs, provide assistance to schools, matters relating to children, not giving up children's affairs to schools, assuming parents as school partners, not overdemanding school, helping as needed, controlling children's education strictly, not bothering schools, following school development, feeling children safe in school, and care about children's education. So, as stated by Okim Komarudin (2015: 183) that "ideal conditions" occur when the involvement of parents is optimal, then in these two schools it can be said, theoretically "there is hope for the realization of ideal conditions in school relations (teachers) with parents in the process education.

2. Perception as a Consideration for Choosing a School

Perception turns out according to Rachmat (2000: 57) explains that perception is influenced by culture. In this case, it is estimated that there is an influence of previous experience on the consideration of parents to choose a school. In addition, factors that are personal and situational factors (Krech and Crutchfield, 1977: 235 quoted by Rachmat, 2000: 51). Based on research data, the factors that were considered "very important" in choosing schools were (1) complete school facilities, (2) results of school graduates, (3) relationships with good schools, (4) guaranteed child moral education, (5) achievements students, (6) community views on schools, (7) good school and parent cooperation, (8) schools do not bother parents, (9) there is a sense of security in school children in the school. Other aspects that are considered "important enough" are (1) school activities, discipline, teacher attention, (2) distance from school to home, and (3) good experience with school in the past.

3. School efforts involve parents in school education

Things that should be avoided, as stated by Alan Thomas (quoted by Rose and Nicholl, 2002: 364) that school education seems to cover everything the teacher wants but is rarely achieved. That is, the teacher "feels unnecessary" (tends to close himself) involving parents. Relating to "parental involvement in the education process in schools." Data from parents and teachers at Santun Untan Senior High School and Gembala Baik Senior High School shows that the "very important" aspect is the involvement of parents and teachers in terms of (1) cultivation of character, (2) creating an atmosphere of learning, (3) choosing schools, (4) supporting children to take extra curricula, (5) fulfilling school invitations, (6) fulfilling children's school needs, and (7) giving support to school activities. Other aspects, such as (1) giving time to accompany learning, (2) accompanying children to learn, (3) giving input requested or not, (4) holding formal discussions / not being considered "important enough".

4. Improving the Quality of School and Parent Relations

Anita E. Woolfolk, Lorraine McCune-Nicolich (Educational Psychology for Teachers, 1984: 197) explains that "perception refers to the meaning we attach to information received through our sense. Many factors influence perception, including expectations, beliefs, and general saver principles for organizing information from the senses ". Perceptions about the quality of school and parent relationships are related to the views of parents and schools about their respective duties and roles in the education process of students. So, the object of perception is the task and role of parents and teachers in educational activities in schools. In this study, parents' relationships with schools (teachers) were described, among others through (1) giving motivation to children, (2) the existence of parent-school links, (3) discussion of children's problems, (4) supervision of children's activities, (5) remind children of learning habits, (6) align attitudes towards children, and (7) help children develop creativity related to subjects and interests. In Santun Untan Senior High School and Gembala Baik Senior High School Good aspects that are considered "very important" in improving the quality of cooperative relations between the two are (1) motivating children, (2) supervising children's activities, (3) improving good habits in children, (4) explain children's attitudes, and (5) help children develop creativity related to subjects and interests, (6) attitudes alignment with children, and (7) discussion of child problems. So, the expectations and beliefs of the school towards parents greatly determine the quality and form of parental involvement in the education process at school.

5. Difficulties in School Relations with Parents of Senior

High Schools Santun Untan

Referring to the opinion of Alan Thomas (quoted by Rose and Nicholl, 2002: 364) that (1) education in schools seems to cover everything the teacher wants, but is rarely achieved, (2) perceptions are determined by personal factors and situational factors (Krech and Crutchfield, 1977: 235, quoted by Rachmat, 2000: 51), and (3) that perceptions are influenced by culture (Rachmat, 2000: 57), then the relationship between schools and parents will depend on the teacher and the community school, parents, and culture (in school and parents). The wider the cultural differences on both sides, the more difficult it will be to create optimal cooperation. Aspects that are thought to be obstacles to cooperation between the two, which are examined are (1) whether there are difficulties meeting with the principal, (2) whether there are difficulties meeting the homeroom teacher, (3) whether there are difficulties meeting the teacher, (4) 
whether there are difficulties conveying suggestions, (5) whether there are difficulties in building cooperation, (6) whether there are difficulties in discussing student problems, and (7) is there any difficulty in knowing the score of students. Among the seven aspects asked, both at Santun Untan Senior High School and Gembala Baik Senior High School Both teachers and parents stated "no difficulties", especially in terms of (1) meeting homeroom teachers, (2) meeting teachers, (3) giving suggestions, (4) cooperating, (5) discussing children's interests, and (6) knowing children's scores. The aspect that gets an "easy enough" assessment is to meet with the principal. From the results of this study, there is hope in Santun Untan Senior High School and Gembala Baik Senior High School to build optimal cooperation in student education.

\section{CONCLUSION}

The perceptions of parents and teachers in Santun Untan Senior High School and Gembala Baik Senior High School on the relationship of parents to teachers are considered "good." Aspects that are considered "important" to "very important" in the relationship between parents and teachers include; do not consider the parents do not understand school matters, matters relating to children, do not hand over child affairs to schools, consider parents as school partners, do not overdo school demands, help as needed, control children's education, parents do not bother the school, keep up with developments school, feel children are safe at school and care about children's education. With such perceptions, it is possible to "ideal conditions" in school relations (teachers) with parents in the process of student education. Factors that are considered "very important" in choosing schools include completeness of school facilities, results of school graduates, relations with good schools, guaranteed child moral education, community views on schools, school cooperation and good parents; there is a sense of security for school children at the school. Regarding "parent involvement in the education process at school", parents and teachers at Santun Untan Senior High School and Gembala Baik Senior High School stated that "very important" things were planting character, creating an atmosphere of learning, choosing schools, supporting children attend extra curricula, fulfill school invitation, fulfill the school needs of children, and provide support for school activities. The quality of school and parent relations in both schools is influenced by supervision of children's activities, efforts to improve good habits in children, and efforts to help children develop creativity related to subjects and interests. Difficulties in creating optimal cooperation in both schools were assessed by teachers and parents "no difficulties." From the results of this study, there is hope that Santun Untan Senior High School and Gembala Baik Senior High School can build optimal cooperation in student education.

\section{REFERENCES}

Goleman Daniel. Emotional Intelligence (terjemahan $\mathrm{T}$. Hermaya, 1996). Jakarta: Gramedia Pustaka Utama.

Rakhmat, Jalaluddin. 2000. Psikologi Komunikasi. Bandung: PT Remaja Rosdakarya.

Rose Colin and Nicholl Malcolm J. 2002. Accelerated Learning (terjemahan Dedy Ahimsa, 1997). Bandung: Nuansa.

Ukim Komarudin. 2015. Arief Rachman GURU. Jakarta: Erlangga.

Woolfolk Anita E. And Nicolich Lorraine McCune. 1984. Educational Psychology for Teachers. New Jersey: Prentice-Hall, Inc.

Zamroni. 2000. Paradigma Pendidikan Masa Depan. Yogyakarta: BIGRAF Publishing. 